\title{
CUATSM PET to diagnose age-related diseases: a systematic literature review
}

\author{
Nad’a Majerníková ${ }^{1,2} \cdot$ Jenny Jia Yu² $\cdot$ Andrea B. Maier ${ }^{2,3}$
}

Received: 15 August 2020 / Accepted: 26 September 2020 / Published online: 22 October 2020

(c) The Author(s) 2020

\begin{abstract}
Purpose $\mathrm{Cu}(\mathrm{II})$-diacetyl-bis(N4-methylthiosemicarbazone) positron emission tomography (CuATSM PET) is a non-invasive imaging technique that can be used to detect hypoxia and inform prognosis in cancer. Hypoxia and oxidative stress are also hallmarks of various age-related diseases. Whether CuATSM PET has a role in the evaluation of hypoxia and oxidative stress in age-related diseases has yet to be established. The aim of this systematic review is to evaluate the utility of CuATSM PET in the diagnosis and management of age-related diseases.

Methods EMBASE, Medline, Scopus, Web of Science and Psychinfo were systematically searched for articles published between January $1^{\text {st }} 1997$ and February 13th 2020. We included articles published in English reporting the use of CuATSM PET in the diagnosis and management of age-related diseases in humans or animals.

Results Nine articles were included describing CuATSM PET measures in neurological and cardiovascular disease. There was higher CuATSM uptake in diseased compared to control subjects in Parkinson's disease (PD), amyotrophic lateral sclerosis (ALS), myocardial ischemia (MI), cardiac dysautonomia and atherosclerosis. Higher CuATSM uptake was seen in diseased compared to control anatomical areas in PD, cerebrovascular disease (CVD), MI and atherosclerosis. CuATSM uptake was associated with disease severity in PD, ALS, CVD and atherosclerosis. An association between CuATSM uptake and disease duration was shown in atherosclerosis.

Conclusion CuATSM uptake is higher in neurological and cardiovascular diseases and associated with disease severity and duration. Further investigations using CuATSM PET in other age-related diseases are needed.
\end{abstract}

Keywords Positron-emission tomography $\cdot$ Hypoxia $\cdot$ Ferroptosis $\cdot$ Aged $\cdot$ Nervous system disease $\cdot$ Cardiovascular disease $\cdot$ Morbidity

\section{Introduction}

Aging is associated with an increased risk of developing age-related disease [1]. Age-related diseases, such as neurological and cardiovascular diseases, represent the leading

Andrea B. Maier

a.b.maier@vu.nl

1 Faculty of Science and Engineering, University of Groningen, Groningen, Netherlands

2 Department of Medicine and Aged Care, @ AgeMelbourne, The Royal Melbourne Hospital, The University of Melbourne, Victoria, Australia

3 Department of Medicine and Aged Care, @ Age, Department of Human Movement Sciences, Faculty of Behavioural and Movement Sciences, VU University Amsterdam, Amsterdam Movement Sciences, van der Boechorststraat 7, 1081 BT Amsterdam, The Netherlands cause of death worldwide [2,3]. Many of these diseases share important hallmarks of aging including accumulation of DNA damage [4], mitochondrial dysfunction [5], decreased autophagy [6], and production of reactive oxygen species (ROS) [7]. The latter can lead to oxidative stress and hypoxia $[7,8]$, which in turn can induce ferroptosis [9, 10]. This iron-dependent programmed cell death is seen in age-related diseases such as Parkinson's disease (PD) [11], Alzheimer's disease (AD) $[12,13]$ and cardiovascular diseases [14].

$\mathrm{Cu}(\mathrm{II})$-diacetyl-bis(N4-methylthiosemicarbazone) (CuATSM), first developed as a positron emission tomography (PET) hypoxia marker [15], has been used to evaluate tumor hypoxia, predict disease prognosis and tailor therapy in various types of cancer [16-19]. More recently, increased CuATSM PET uptake has been seen in PD in the absence of hypoxia [20]. This is thought to be due to CuATSM's ability 
to detect redox changes [21]. Hypoxia and redox changes such as oxidative stress [22] also play an important role in age-related diseases [23-25]. Whether CuATSM PET has a role in the diagnosis and management of age-related human diseases has yet to be established.

The aim of this systematic review is to evaluate the utility of CuATSM PET, as a non-invasive imaging technique, in the diagnosis and management of age-related diseases.

\section{Material and methods}

\section{Protocol registration}

The protocol of the systematic review was registered with the International prospective register of systematic reviews (PROSPERO): CDR/code CRD42020167009. The systematic review was conducted according to the Preferred Reporting Items for Systematic Reviews and Meta-Analyses (PRISMA) standards [26].

\section{Search strategy}

A systematic search was performed with an academic senior liaison librarian (P.C.) in five electronic databases: EMBASE, Medline, Scopus, Web of Science and Psychinfo. The search included keywords: "CuATSM", "PET" and other synonyms of CuATSM ("diacetyl-bis(N4-methylthiosemicarbazone) copper (II)", "diacetyl-di (N4-methylthiosemicarbazone) copper") and all radioactive isotopes of

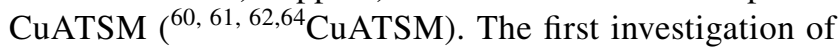
CuATSM as a hypoxia marker was conducted in 1997 [15]. Therefore, articles published between January 1st 1997 and February 13th 2020 were included in this search. The full search strategy is available in Appendix 1. The reference section of each included article was also used to identify additional related articles.

\section{Study selection}

The articles obtained using the search strategy were assessed for eligibility against predefined inclusion and exclusion criteria independently by two authors (J.J.Y. and N.M.) by screening titles and abstracts. The same reviewers then screened the full text of resulting articles. A third reviewer (A.B.M.) resolved any disagreements between the authors regarding eligibility. Inclusion criteria were: articles using CUATSM PET in the diagnosis and management of agerelated diseases in humans or animals, published in English Opinion articles, conference abstracts, editorials, letters to the editor, and case reports were excluded.

\section{Data extraction and quality assessment}

The following variables were extracted independently by two reviewers (J.J.Y. and N.M.) from the included studies: first author, year of publication, title, study design, study population, sample size, age, proportion of females, country, agerelated disease studied, intervention, primary purpose of the scan, type of PET tracer, duration of the scan, scan results, clinical outcomes measured, other reported outcomes, adverse events related to intervention and statistical analysis used.

Articles were assessed for their risk of bias independently by two reviewers (J.J.Y. and N.M.) using the Newcastle Ottawa Scale (NOS) for cohort studies [27, 28]. A system of points was given to the following categories: (i) selection of the study population, (ii) comparability, and (iii) description of the outcome (Appendix 2). A study was given a maximum of one point in each item within the "selection" and "outcome" categories and a maximum of two points in the "comparability" category. The scores ranged from 0 to 9. A score of seven or more was classified as high quality.

\section{Analysis}

We summarized the difference between CuATSM uptake in diseased and control subjects, and between diseased and control anatomical areas. Additionally, the association between CuATSM uptake and severity and duration of agerelated disease was summarized.

\section{Results}

\section{Search strategy}

The search retrieved 9633 articles. After exclusion of duplicates $(n=5774)$, articles were screened for title and abstracts of which 244 were screened for full text and nine articles were included in this review (Fig. 1).

\section{Study characteristics}

The included articles were classified according to the type of age-related disease: neurological (four articles) and cardiovascular disease (five articles) (Table 1). A total of 46 humans with neurological disease (mean age $62.7 \pm 6.58$ years, $n=19$ female) and 22 controls (mean age $43.6 \pm 8.33$ years, $n=3$ female) as well as seven humans with cardiovascular disease (aged 63-80 years, $n=3$ female (no controls)) were included. A range of animal models including dog, macaque, rabbit and mouse served to study cardiovascular disease (total $n=40$ diseased subjects and $n=7$ controls). The aim of all included articles was to use CuATSM PET to diagnose or prognosticate 
Fig. 1 Flow chart of the study selection process
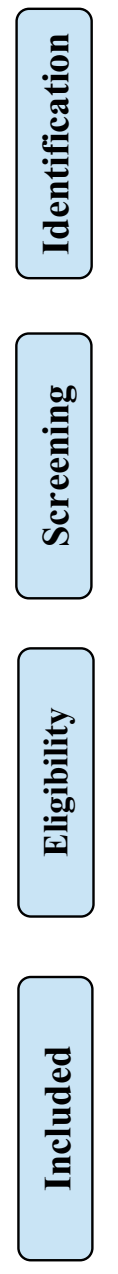

Table 1 Characteristics of included articles assessing the utility of CuATSM PET in age-related diseases

\begin{tabular}{|c|c|c|c|c|c|c|c|c|c|c|c|c|}
\hline \multirow[t]{2}{*}{ Author (year) } & \multirow[t]{2}{*}{ Species } & \multicolumn{4}{|c|}{ Diseased subjects } & \multicolumn{4}{|c|}{ Control subjects } & \multicolumn{3}{|c|}{ CuATSM PET scan } \\
\hline & & Type & $\mathrm{N}$ & 우 & Age, years & Type & $\mathrm{N}$ & q & Age, years & ${ }^{*} \mathrm{Cu}$ & Type (duration, min) & Anatomical location \\
\hline \multicolumn{13}{|l|}{ Neurological disease } \\
\hline Ikawa (2011) & Human & PD & 15 & 8 & $72.2 \pm 9.4$ & $\mathrm{HC}$ & 6 & 0 & $34.7 \pm 9.0$ & 62 & Dynamic (20) & Brain-striatum \\
\hline Ikawa (2015) & Human & ALS & 12 & 5 & $65.2 \pm 9.4$ & $\mathrm{HC}$ & 9 & 3 & $61.2 \pm 8.0$ & 62 & Dynamic (20) & Whole-brain \\
\hline Isozaki (2011) & Human & CVD & 10 & 3 & $66 \pm 7$ & $\mathrm{HC}$ & 7 & 0 & $35 \pm 8$ & 62 & Dynamic (20) & Whole-brain \\
\hline Neishi (2017) & Human & PD & 9 & 3 & $67.3 \pm 7.1$ & NA & 0 & NA & NA & 62 & Dynamic (20) & Brain-striatum \\
\hline \multicolumn{13}{|c|}{ Cardiovascular disease } \\
\hline Lewis (2002) & Dog & MI & 16 & 0 & NR & NA & 0 & NA & NA & 64 & Dynamic (60) & Myocardium \\
\hline Metzger (2018) & Macaque & $\mathrm{CD}$ & 10 & 0 & Adult & NA & 0 & NA & NA & 61 & Dynamic (45) & Heart \\
\hline Nie (Dec 2016) & Rabbit & ATH & 5 & NR & NR & NA & 0 & NR & NA & 64 & Dynamic (60) & Femoral artery \\
\hline Nie (Sep 2016) & Mouse & ATH & 9 & NR & 1 & WT & 7 & NR & 0.83 & 64 & Dynamic (30) & Aortic arch \\
\hline Takahashi (2001) & Human & CAD & 7 & 3 & [63-80] & NA & 0 & NA & NA & 62 & Static (10) & Myocardium \\
\hline
\end{tabular}

$A L S$ amyotrophic lateral sclerosis, $A T H$ atherosclerosis, $C A D$ coronary artery disease, $C D$ cardiac dysautonomia, $C V D$ cerebrovascular disease, ${ }^{*} \mathrm{Cu}$ type of $\mathrm{Cu}$ copper isotope, $H C$ healthy controls, $M I$ myocardial ischemia, $N$ sample size, $N A$ not applicable, $N R$ not reported, $P D$ Parkinson's disease $W T$ wild type. Mean $\pm \mathrm{SD}$, [range] 
age-related diseases. The $\mathrm{Cu}$ isotope, type, duration and anatomical location of the scan differed according to the disease and type of subjects studied. All articles describing neurological diseases used a 20 min dynamic ${ }^{62}$ CuATSMPET scan and measured standard uptake value (SUV) in the brain: striatum for PD [20, 29], whole-brain for ALS [30] (Fig. 2a) and cerebrovascular disease [31] (Fig. 2b). All cardiovascular disease articles used dynamic 30-60 min PET scan except one which used static 10 min PET scan data [32] (Fig. 2c). The ${ }^{64} \mathrm{Cu}$ isotope was used to image atherosclerosis in rabbit and mouse [33, 34] and myocardial ischemia (MI) in dogs [35]. The ${ }^{61} \mathrm{Cu}$ isotope was used to image cardiac dysautonomia in macaques [36] and ${ }^{62} \mathrm{Cu}$ for coronary artery disease (CAD) in humans [32].

A

Neurological disease

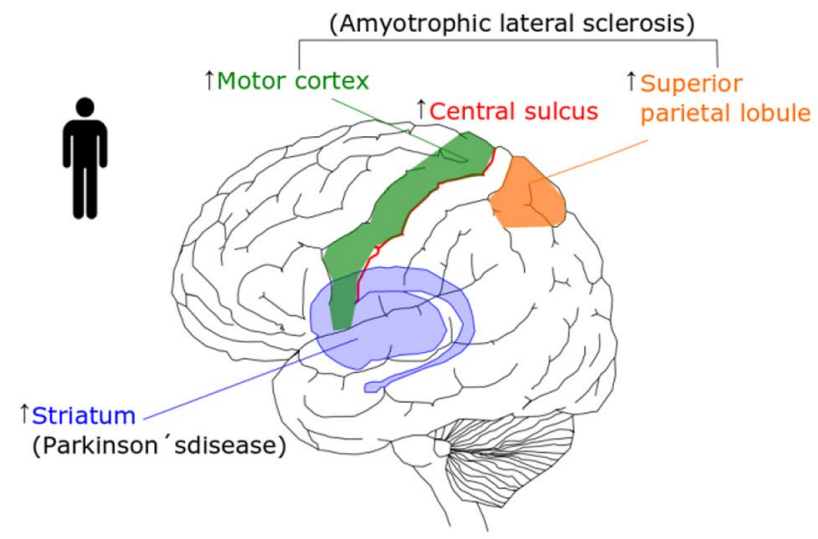

B Cerebrovascular disease

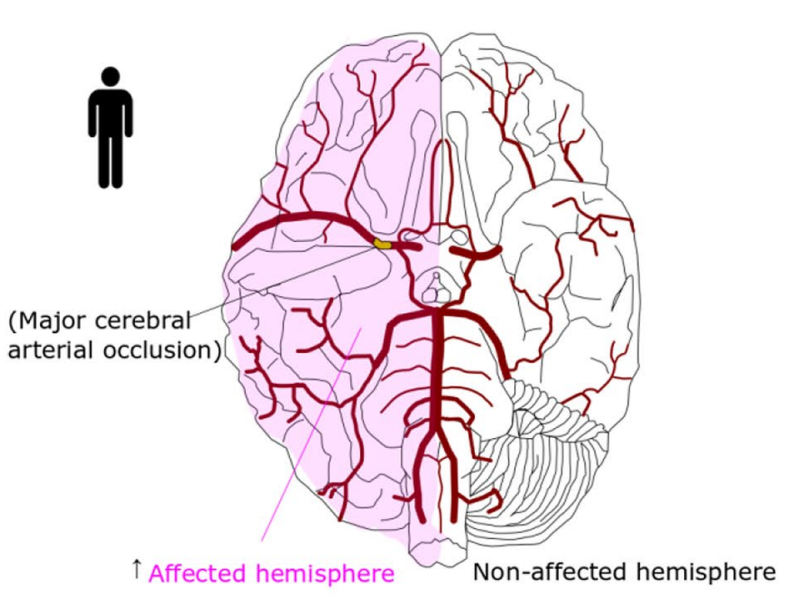

Fig. 2 Distribution patterns of CuATSM uptake in age-related diseases. Distribution patterns of PET CuATSM uptake seen in included studies. a Human Parkinson's disease and amyotrophic lateral sclero-

\section{Quality assessment}

The total NOS scores are shown in Appendix 3. Three articles $[30,33,35]$ were scored as high quality and the remaining as medium quality.

\section{Qualitative description of CuATSM PET uptake and age-related diseases}

Table 2 shows the difference in CuATSM uptake in diseased compared to control subjects, and diseased compared to control anatomical areas, as well as the association of CuATSM uptake with disease severity and duration. Compared to healthy controls, CuATSM uptake was higher in the

C Cardiovascular disease
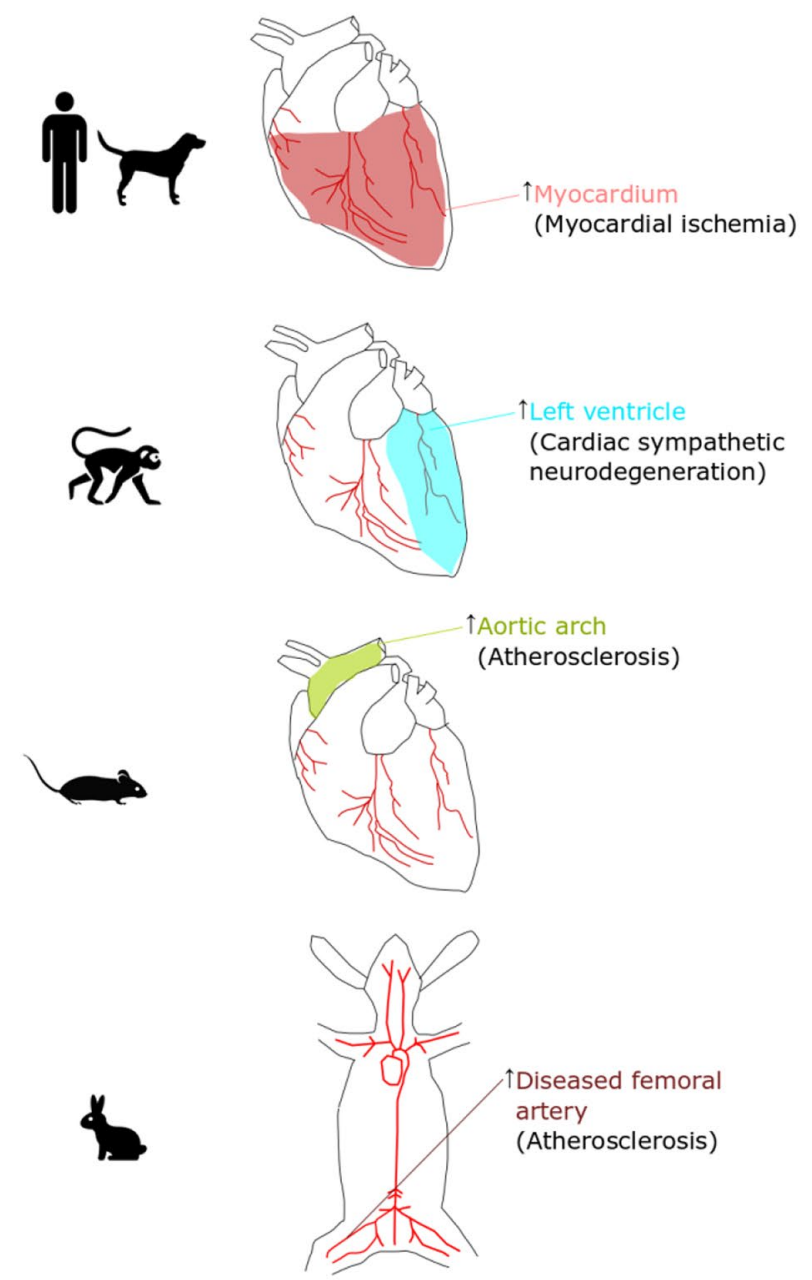

sis studies [20, 29, 30]; (b) human cerebrovascular diseases studies [31]; (c) human, dog, macaque, mouse and rabbit cardiovascular disease studies [32-36] 
striatum of PD patients and the bilateral cortices around the central sulcus, including the motor cortex and right superior parietal lobule, of ALS patients [20, 30]. Higher CuATSM uptake was seen in affected compared to non-affected hemispheres in PD patients [29]. CuATSM uptake in the brain was significantly associated with disease severity expressed as the total and motor unified Parkinson's disease rating scale (UPDRS) in PD patients [20, 29] and revised amyotrophic lateral sclerosis functional rating scale (ALSSFR-S) in ALS patients [30]. No association was observed between CuATSM uptake and ALS disease duration [30], while a positive trend was observed between CuATSM uptake and PD duration [20].

Compared to controls, higher CuATSM uptake was detected in the myocardium of dogs after MI, the anterior ventricle of macaques with cardiac dysautonomia and in the aortic arch of mice with atherosclerosis [34-36]. CuATSM uptake was greater in affected compared to non-affected hemispheres in patients with unilateral major cerebral artery occlusion [31], in ischemic compared to normal tissue in dog myocardium and in injured (modelling atherosclerosis) compared to the non-injured femoral artery of rabbits [33, 35]. CuATSM uptake was significantly associated with disease severity expressed as the oxygen extraction fraction $(\mathrm{OEF})$ in patients with unilateral major cerebral artery occlusion [31] and with the degree of thickening of the vessel wall in rabbits with atherosclerosis [33]. CuATSM uptake increased significantly from 14 to 23 weeks after atherosclerosis induction in mice [34] suggesting an association between CuATSM uptake and duration of atherosclerosis. Finally, CuATSM uptake was enhanced in one patient with unstable angina compared to patients with stable coronary artery disease [32]. The heterogeneity of study designs and outcome measures precluded a meta-analysis.

\section{Discussion}

CuATSM uptake was higher in human and animal subjects with neurological and cardiovascular disease compared to controls and in diseased compared to non-diseased anatomical areas. CuATSM uptake was positively associated with disease severity and duration.

\section{CUATSM PET and neurological diseases}

Currently, neurodegenerative diseases like PD and ALS can only be diagnosed when symptoms manifest, while biomarkers allowing earlier detection remain elusive [37-39]. Hypoxia and oxidative stress are associated with cell death mechanisms involved in ALS and PD [40, 41]. Thus, using $\mathrm{CuATSM}$ as a redox change biomarker could lead to earlier detection of neurodegenerative diseases [42]. Due to its sensitivity to disease severity in ALS, PD and cerebrovascular disease [20, 29-31], CuATSM PET could also be used as a tool for monitoring therapy. Additionally, vascular cognitive impairment, in part caused by chronic cerebral hypoperfusion [43], is generally not detected until patients present with cognitive decline [44]. Therefore, using CuATSM PET to detect chronic hypoperfusion may result in earlier diagnosis and intervention in cognitive impairment and dementia [45].

\section{CuATSM PET and cardiovascular diseases}

CuATSM PET provides a quantitative assessment of myocardial ischemia in research [35] and clinical settings [32] and shows promise in diagnosing systemic atherosclerosis in research settings $[33,34,46]$, but its utility has not yet been translated into clinical practice. Animal and human studies show the presence of hypoxia in atherosclerotic plaques and its link to plaque rupture $[47,48]$. Thus, using CuATSM PET to image hypoxia in atherosclerosis may provide important pathophysiological insight and help identify vulnerable atherosclerotic plaques, which could leave to improved patient management [49].

\section{CuATSM PET and other age-related diseases}

No evidence of the use of CuTASM PET in the detection of hypoxia and oxidative stress in age-related diseases was found other than in neurological and cardiovascular diseases. Other age-related diseases associated with redox changes include chronic kidney disease [50], urinary tract infections [51], type 2 diabetes mellitus [52] and sarcopenia [53]. Hypoxia in tubulointerstitium and glomerular oxidative stress play a role in chronic kidney disease progression $[54,55]$, although blood oxygen level-dependent magnetic resonance imaging (BOLD-MRI) has failed to demonstrate this association in the past [55-57]. Given the ability of CuATSM PET to detect much lower concentrations of molecules than MRI [58], it may be useful in predicting the progression of chronic kidney disease before any clinical manifestations and hence identify patients who require more intense primary prevention $[59,60]$. Urinary tract infections are associated with oxidative stress [61] and the accumulation of hypoxia-inducible factor- $1 \alpha$ subunit (HIF-1 $\alpha$ ) [62]. HIF- $1 \alpha$ is also induced by hyperglycemia in diabetes [63, 64], where inhibition of HIF- $1 \alpha$ leads to decreased insulin resistance [65]. Thus, CuATSM PET may also be useful in research into the pathogenesis of recurrent urinary tract infections [66, 67] and insulin resistance [68]. Recent evidence suggests that oxidative stress and hypoxia play a role in the development of sarcopenia [53,69]. Given the current need for new imaging tools for sarcopenia [70], the potential 


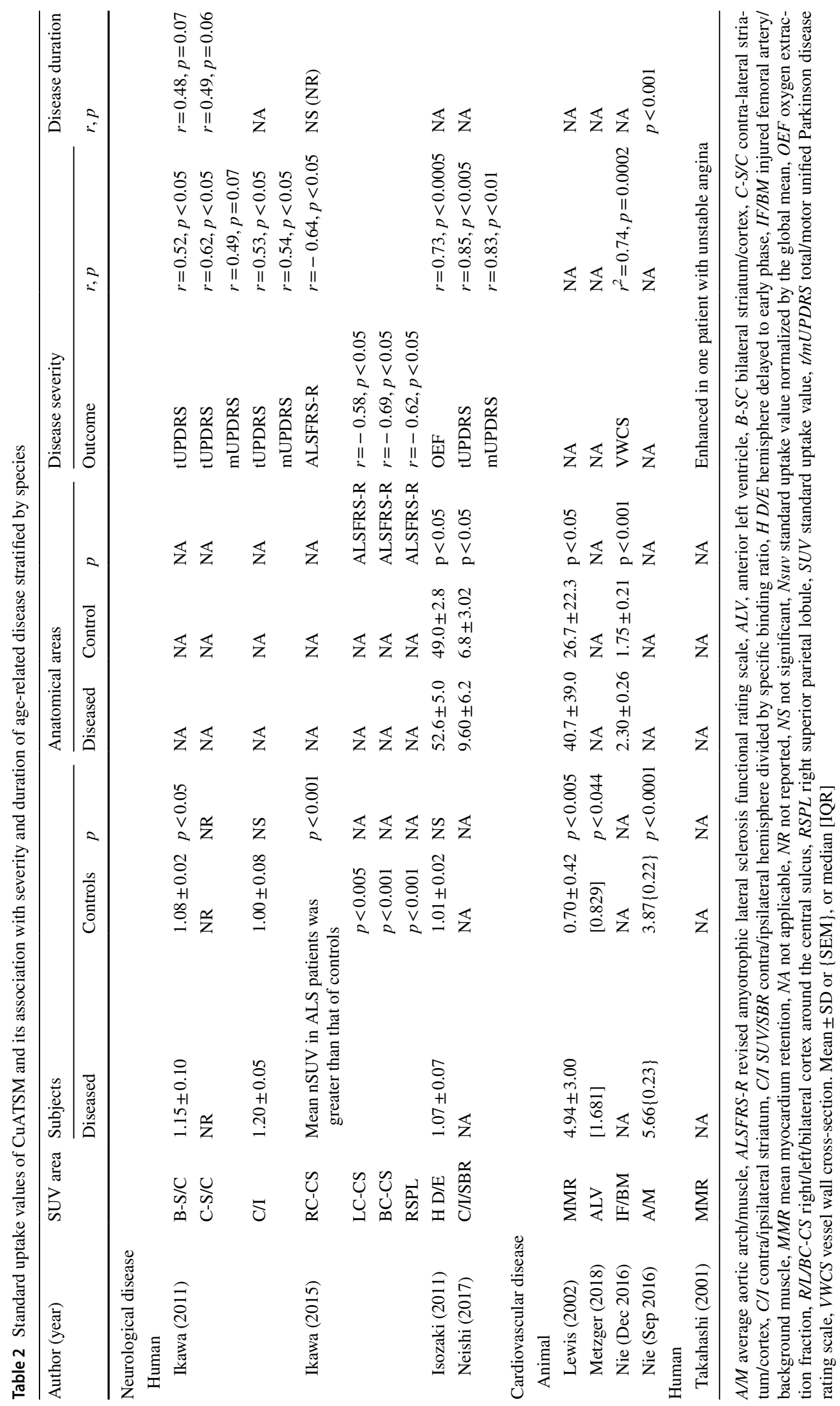


of CuATSM PET as a non-invasive diagnostic tool for identifying sarcopenia in older adults should be explored.

\section{The potential clinical use of CUATSM PET in age-related diseases}

This review has demonstrated the ability of CuATSM PET to delineate hypoxic tissue and showed the association between CuATSM uptake with disease severity in neurologic and cardiac diseases in clinical and pre-clinical models. Given these results, potential future clinical applications of CuATSM PET include disease detection prior to symptom manifestation allowing improved risk factor management, earlier disease diagnosis and sensitive monitoring of disease activity. To achieve clinical translation, future research should focus on studies in humans with larger sample sizes and robust study designs in the diseases already studied, as well as examining a broader range of age-related diseases in which hypoxia and oxidative stress are implicated.

\section{lonic $\mathrm{Cu}$ (II) salts as imaging tracers for age-related diseases}

PET CuATSM uptake in cancer and age-related diseases has been demonstrated in preclinical and clinical studies. Interestingly, PET uptake of ionic copper $\mathrm{Cu}$ (II) salts, such as $\left[{ }^{64} \mathrm{Cu}\right] \mathrm{CuCl}_{2}$, has also been seen in various cancer xenografts [71] and was found to be comparable to CuATSM in imaging and therapeutic cancer studies [72]. The mechanism of tissue uptake of CuATSM and ionic $\mathrm{Cu}$ (II) salts, however, remain controversial [73]. Given the redox changes common to both cancer and age-related diseases, future studies focusing on these mechanisms may clarify to whether $\mathrm{Cu}$ (II) salts could also be used in research into age-related diseases [73].

\section{Strengths and limitations}

To our knowledge, this is the first systematic review examining the utility of CuATSM PET in the diagnosis and management of age-related diseases. So far, there are only a few studies in this area with heterogeneous study design and small number of study subjects which precluded a meta-analysis. All included articles reported on the diagnostic capacity of CuATSM PET but not on its utility in the management of age-related disease. Given the specificity of CuATSM as an imaging biomarker of hypoxia has been challenged previously [74], we would have liked to report on the sensitivity and specificity of the CuATSM PET scans used in the articles included in this review. However, only one of these articles reported these parameters [31]. This limits the translational potential of the results to clinical and other research settings. Finally, healthy controls in many of these studies were not matched for age and sex.

\section{Conclusions}

Hypoxia, oxidative stress and ferroptosis are important hallmarks of various age-related diseases [11-14, 23, 75, 76]. CuATSM PET is a non-invasive imaging technique that detects hypoxia and oxidative stress in neurological and cardiovascular diseases [23-25, 77, 78]. The clinical potential of CuATSM PET in early diagnosis, disease prognostication and monitoring disease activity $[79,80]$ and its utility in research settings in other age-related diseases, such as chronic kidney disease, recurrent urinary tract infections, diabetes and sarcopenia, should be investigated further.

Acknowledgements The authors would like to thank Patrick Condron (senior liaison librarian, Brownless Biomedical Library, Faculty of Medicine, Dentistry \& Health Sciences, the University of Melbourne), who greatly assisted with the construction of the search strategy. PROSPERO registration number: CRD 42020167009

Author contributions All authors made substantial contributions to the design of the review, the acquisition, analysis, and interpretation of data; drafted the work or revised it critically for important intellectual content; approved the version to be published; and agree to be accountable for all aspects of the work in ensuring that questions related to the accuracy or integrity of any part of the work are appropriately investigated and resolved.

Funding This study was supported by an unrestricted grant of the University of Melbourne, Australia received by Professor Andrea B. Maier.

Data availability Not applicable.

\section{Compliance with ethical standards}

Conflict of interest None of the authors reported any conflict of interest.

Consent for publication All authors have read and approved all versions of the manuscript, its contents, and submission.

Open Access This article is licensed under a Creative Commons Attribution 4.0 International License, which permits use, sharing, adaptation, distribution and reproduction in any medium or format, as long as you give appropriate credit to the original author(s) and the source, provide a link to the Creative Commons licence, and indicate if changes were made. The images or other third party material in this article are included in the article's Creative Commons licence, unless indicated otherwise in a credit line to the material. If material is not included in the article's Creative Commons licence and your intended use is not permitted by statutory regulation or exceeds the permitted use, you will need to obtain permission directly from the copyright holder. To view a copy of this licence, visit http://creativecommons.org/licenses/by/4.0/. 


\section{Appendix 1 Full search strategy}

1. (ferroptosis or ferroptotic or ((iron or ferrous or ferritin or ferric) adj5 (cell death or apoptosis))).mp.

2. ((((oxidative or oxidation) adj2 glutamate) or ((oxidative or oxidation) adj2 glutamic)) adj4 (toxic* or death)).mp.

3. 1 or 2

4. (CuATSM or ATSM or methylthiosemicarbazonato or methylthiosemicarbazone or Cu62ATSM or Cu61ATSM or Cu63ATSM or Cu64ATSM or Cu60ATSM or 62CuATSM or 61CuATSM or 63CuATSM or 64CuATSM or 60CuATSM).mp.

5. 3 or 4 


\section{Appendix 2 Newcastle-Ottawa quality assessment scale}

\section{NEWCASTLE - OTTAWA QUALITY ASSESSMENT SCALE \\ COHORT STUDIES}

Note: A study can be awarded a maximum of one star for each numbered item within the

Selection and Outcome categories. A maximum of two stars can be given for Comparability.

Selection

1) Representativeness of the exposed cohort

a) truly representative of the average age-related disease in human or animal subjects*

b) somewhat representative of the average age-related disease in human or animal subject

c) selected group of users eg nurses, volunteers

d) no description of the derivation of the cohort

2) Selection of the non exposed cohort

a) drawn from the same community as the exposed cohort*

b) drawn from a different source

c) no description of the derivation of the non exposed cohort

3) Ascertainment of exposure

a) secure record (eg surgical records) *

b) structured interview*

c) writtenself report

d) no description

4) Demonstration that outcome of interest was not present at start of study

a) yes*

b) no

Comparability

1) Comparability of cohorts on the basis of the design or analysis

a) study controls for age or sex*

b) study controls for age and sex*

Outcome

1) Assessment of outcome

a) independent blind assessment*

b) record linkage*

c) self report

d) no description

2) Was follow-up long enough for outcomes to occur

a) yes $\left({ }^{60} \mathrm{Cu}: 23.4 \mathrm{~min}\right.$ half-life, ${ }^{61} \mathrm{Cu}: 3.4 \mathrm{~h}$ half-life, ${ }^{62} \mathrm{Cu}$ : $9.7 \mathrm{~min}$ half-life, ${ }^{64} \mathrm{Cu}: 12.7 \mathrm{~h}$

half-life) *

b) no

3) Adequacy of follow up of cohorts

a) complete follow up - all subjects accounted for*

b) subjects lost to follow up unlikely to introduce bias - small number lost ( $>20 \%$ follow

up, or description provided of those lost) *

c) follow up rate $<20 \%$ and no description of those lost

d) no statement 


\section{Appendix 3 Quality assessment of included articles using the Newcastle-Ottawa Scale}

\begin{tabular}{|c|c|c|c|c|c|c|c|c|c|c|}
\hline \multirow[t]{2}{*}{ Author (year) } & \multicolumn{4}{|l|}{ Selection } & \multirow{2}{*}{$\begin{array}{l}\text { Comp } \\
\text { Adjustment } \\
\text { for con- } \\
\text { founders }\end{array}$} & \multicolumn{3}{|l|}{ Outcome } & \multirow[t]{2}{*}{ Score } & \multirow[t]{2}{*}{ Quality } \\
\hline & $\begin{array}{l}\text { Representa- } \\
\text { tiveness }\end{array}$ & Selection & $\begin{array}{l}\text { Ascertain- } \\
\text { ment }\end{array}$ & $\begin{array}{l}\text { Outcome } \\
\text { was not } \\
\text { present } \\
\text { at start of } \\
\text { study }\end{array}$ & & $\begin{array}{l}\text { Ascertain- } \\
\text { ment }\end{array}$ & $\begin{array}{l}\text { Duration } \\
\text { of follow- } \\
\text { up }\end{array}$ & $\begin{array}{l}\text { Com- } \\
\text { plete-ness } \\
\text { of follow- } \\
\text { up }\end{array}$ & & \\
\hline \multicolumn{11}{|l|}{ Neurological } \\
\hline Ikawa (2011) & $*$ & - & $*$ & - & - & $*$ & $*$ & $*$ & 5 & M \\
\hline Ikawa (2015) & $*$ & - & $*$ & - & $* *$ & $*$ & $*$ & $*$ & 7 & $\mathrm{H}$ \\
\hline Isozaki (2011) & $*$ & - & $*$ & - & - & $*$ & $*$ & $*$ & 5 & M \\
\hline Neishi (2007) & $*$ & - & $*$ & - & - & $*$ & $*$ & $*$ & 5 & M \\
\hline \multicolumn{11}{|l|}{ Cardiovascular } \\
\hline Lewis (2002) & - & $*$ & $*$ & $*$ & $* *$ & $*$ & $*$ & $*$ & 8 & $\mathrm{H}$ \\
\hline $\begin{array}{r}\text { Metzger } \\
(2018)\end{array}$ & - & - & $*$ & $*$ & - & $*$ & $*$ & $*$ & 5 & M \\
\hline $\begin{array}{l}\text { Nie (Dec } \\
2016)\end{array}$ & $*$ & $*$ & $*$ & - & $* *$ & $*$ & $*$ & $*$ & 8 & $\mathrm{H}$ \\
\hline $\begin{array}{l}\text { Nie (Sep } \\
2016)\end{array}$ & $*$ & - & $*$ & - & $*$ & $*$ & $*$ & $*$ & 6 & M \\
\hline $\begin{array}{c}\text { Takahashi } \\
\text { (2001) }\end{array}$ & $*$ & - & $*$ & - & - & $*$ & $*$ & $*$ & 5 & M \\
\hline
\end{tabular}

Number of stars (*): 1-3, low quality (L); 4-6, medium quality (M); 7-9, high quality (H). Comp: comparability.

\section{References}

1. Marengoni A, Angleman S, Melis R, Mangialasche F, Karp A, Garmen A et al (2011) Aging with multimorbidity: a systematic review of the literature. Ageing Res Rev 10(4):430-439. https:// doi.org/10.1016/j.arr.2011.03.003

2. Feigin VL, Nichols E, Alam T, Bannick MS, Beghi E, Blake N et al (2019) Global, regional, and national burden of neurological disorders, 1990-2016: a systematic analysis for the Global Burden of disease study 2016. Lancet Neurol 18(5):459-480. https://doi. org/10.1016/S1474-4422(18)30499-X

3. World Health Organization. Global health estimates 2018: disease burden by cause, sex, by country and region, 2000-2016. World Health Organization. 2018. https://www.who.int/healthinfo /global_burden_disease/estimates/en/index1.html. Accessed 13 Apr 2020.

4. Chen X, Xie C, Tian W, Sun L, Wang Z, Hawes S et al (2020) Parkinson ' $s$ disease-related Leucine-rich repeat kinase 2 modulates nuclear morphology and genomic stability in striatal projection neurons during aging. Mol Neurodegener 15(1):12. https://doi. org/10.1186/s13024-020-00360-0

5. Alexeyev M, Shokolenko I, Wilson G, LeDoux S (2013) The maintenance of mitochondrial DNA integrity-critical analysis and update. Cold Spring Harb Perspec Biol 5(5):a012641. https ://doi.org/10.1101/cshperspect.a012641

6. Gaziev AI, Abdullaev S, Podlutsky A (2014) Mitochondrial function and mitochondrial DNA maintenance with advancing age. Biogerontology 15(5):417-438. https://doi.org/10.1007/s1052 2-014-9515-2

7. Hoeijmakers JHJ (2009) DNA damage, aging, and cancer. N Engl J Med 361(15):1475-1485. https://doi.org/10.1056/NEJMra0804 615

8. Davalli P, Mitic T, Caporali A, Lauriola A, D'Arca D (2016) ROS, cell senescence, and novel molecular mechanisms in aging and age-related diseases. Oxid Med Cell Longev 2016:3565127. https ://doi.org/10.1155/2016/3565127

9. Hirschhorn T, Stockwell BR (2019) The development of the concept of ferroptosis. Free Radic Biol Med 133:130-143. https://doi. org/10.1016/j.freeradbiomed.2018.09.043

10. Guiney SJ, Adlard PA, Bush AI, Finkelstein DI, Ayton S (2017) Ferroptosis and cell death mechanisms in Parkinson's disease. Neurochem Int 104:34-48. https://doi.org/10.1016/j.neuin t.2017.01.004

11. Van Do B, Gouel F, Jonneaux A, Timmerman K, Gelé P, Pétrault $M$ et al (2016) Ferroptosis, a newly characterized form of cell death in Parkinson's disease that is regulated by PKC. Neurobiol Dis 94:169-178. https://doi.org/10.1016/j.nbd.2016.05.011

12. Raven EP, Lu PH, Tishler TA, Heydari P, Bartzokis G (2013) Increased iron levels and decreased tissue integrity in hippocampus of Alzheimer's disease detected in vivo with magnetic resonance imaging. J Alzheimers Dis 37(1):127-136. https://doi. org/10.3233/JAD-130209

13. da Rocha TJ, Silva Alves M, Guisso CC, de Andrade FM, Camozzato A, de Oliveira AA et al (2018) Association of GPX1 and GPX4 polymorphisms with episodic memory and Alzheimer's disease. Neurosci Lett 666:32-37. https://doi.org/10.1016/j.neule t.2017.12.026

14. Fang X, Wang H, Han D, Xie E, Yang X, Wei J et al (2019) Ferroptosis as a target for protection against cardiomyopathy. Proc Natl Acad Sci USA 116(7):2672-2680. https://doi.org/10.1073/ pnas. 1821022116

15. Fujibayashi Y, Taniuchi H, Yonekura Y, Ohtani H, Konishi J, Yokoyama A (1997) Copper-62-ATSM: A new hypoxia imaging agent with high membrane permeability and low redox potential. J Nucl Med 38(7):1155-1160 notavailable

16. Takahashi N, Fujibayashi Y, Yonekura Y, Welch MJ, Waki A, Tsuchida $\mathrm{T}$ et al (2000) Evaluation of $62 \mathrm{Cu}$ labeled diacetylbis(N4-methylthiosemicarbazone) as a hypoxic tissue tracer in 
patients with lung cancer. Ann Nucl Med 14(5):323-328. https:// doi.org/10.1007/BF02988690

17. Tsujikawa T, Asahi S, Oh M, Sato Y, Narita N, Makino A et al (2016) Assessment of the tumor redox status in head and neck cancer by 62Cu-ATSM PET. PLoS ONE 11(5):e0155635. https ://doi.org/10.1371/journal.pone.0155635

18. Lewis JS, Laforest R, Dehdashti F, Grigsby PW, Welch MJ, Siegel BA (2008) An imaging comparison of 64Cu-ATSM and $60 \mathrm{Cu}-$ ATSM in cancer of the uterine cervix. J Nucl Med 49(7):11771182. https://doi.org/10.2967/jnumed.108.051326

19. Toriihara A, Ohtake M, Tateishi K, Hino-Shishikura A, Yoneyama T, Kitazume $\mathrm{Y}$ et al (2018) Prognostic implications of 62Cu-diacetyl-bis (N 4-methylthiosemicarbazone) PET/CT in patients with glioma. Ann Nucl Med 32(4):264-271. https://doi.org/10.1007/ s12149-018-1241-4

20. Ikawa M, Okazawa H, Kudo T, Kuriyama M, Fujibayashi Y, Yoneda M (2011) Evaluation of striatal oxidative stress in patients with Parkinson's disease using [62Cu]ATSM PET. Nucl Med Biol 38(7):945-951. https://doi.org/10.1016/j.nucmedbio.2011.02.016

21. Okazawa H, Ikawa M, Tsujikawa T, Kiyono Y, Yoneda M (2014) Brain imaging for oxidative stress and mitochondrial dysfunction in neurodegenerative diseases. Q J Nucl Med Mol Imaging Off Publ Ital Assoc Nucl Med 58(4):387-397 notavailable

22. Liguori I, Russo G, Curcio F, Bulli G, Aran L, Della-Morte D et al (2018) Oxidative stress, aging, and diseases. Clin Interv Aging 13:757-772. https://doi.org/10.2147/CIA.S158513

23. Singh A, Kukreti R, Saso L, Kukreti S (2019) Oxidative stress: a key modulator in neurodegenerative diseases. Molecules 24(8):1583. https://doi.org/10.3390/molecules24081583

24. Chen Y, Qin C, Huang J, Tang X, Liu C, Huang K et al (2020) The role of astrocytes in oxidative stress of central nervous system: a mixed blessing. Cell Prolif 53(3):e12781. https://doi.org/10.1111/ cpr. 12781

25. Daiber A, Chlopicki S (2020) Revisiting pharmacology of oxidative stress and endothelial dysfunction in cardiovascular disease: evidence for redox-based therapies. Free Radic Biol Med S0891-5849(19):31702-31712. https://doi.org/10.1016/j.freer adbiomed.2020.02.026.

26. Moher D, Shamseer L, Clarke 317M, Ghersi D, Liberati A, Petticrew M, et al. Preferred reporting items for systematic review and meta-analysis protocols (PRISMA-P) 2015 statement. Rev Esp. 2015;4(1):1. https://doi.org/10.1186/2046-4053-4-1.

27. Lo CKL, Mertz D, Loeb M (2014) Newcastle-Ottawa scale: comparing reviewers 'to authors' assessments. BMC Med Res Methodol 14:45. https://doi.org/10.1186/1471-2288-14-45

28. Wells G, Shea B, O'Connell D, Peterson J. The Newcastle-Ottawa Scale (NOS) for assessing the quality of nonrandomised studies in meta-analyses. Ottawa, ON: Ottawa Hospital Research Institute. 2000. https://www.ohri.ca/programs/clinical_epidemiology/oxfor d.asp. Accessed 13 Apr 2020.

29. Neishi H, Ikawa M, Okazawa H, Tsujikawa T, Arishima H, Kikuta $\mathrm{KI}$ et al (2017) Precise evaluation of striatal oxidative stress corrected for severity of dopaminergic neuronal degeneration in patients with Parkinson's disease: a study with 62Cu-ATSM PET and 123I-FP-CIT SPECT. Eur Neurol 78(3-4):161-168. https:// doi.org/10.1159/000479627

30. Ikawa M, Okazawa H, Tsujikawa T, Matsunaga A, Yamamura O, Mori $T$ et al (2015) Increased oxidative stress is related to disease severity in the ALS motor cortex. Neurology 84(20):2033-2039. https://doi.org/10.1212/WNL.0000000000001588

31. Isozaki M, Kiyono Y, Arai Y, Kudo T, Mori T, Maruyama R et al (2011) Feasibility of 62Cu-ATSM PET for evaluation of brain ischaemia and misery perfusion in patients with cerebrovascular disease. Eur J Nucl Med Mol Imaging 38(6):1075-1082. https:// doi.org/10.1007/s00259-011-1734-Z
32. Takahashi N, Fujibayashi Y, Yonekura Y, Welch MJ, Waki A, Tsuchida T et al (2001) Copper-62 ATSM as a hypoxic tissue tracer in myocardial ischemia. Ann Nucl Med 15(3):293-296. https://doi.org/10.1007/BF02987849

33. Nie X, Laforest R, Elvington A, Randolph GJ, Zheng J, Voller $T$ et al (2016) PET/MRI of hypoxic atherosclerosis using $64 \mathrm{Cu}-$ ATSM in a rabbit model. J Nucl Med 57(12):2006-2011. https:// doi.org/10.2967/jnumed.116.172544

34. Nie X, Randolph GJ, Elvington A, Bandara N, Zheleznyak A, Gropler RJ et al (2016) Imaging of hypoxia in mouse atherosclerotic plaques with 64Cu-ATSM. Nucl Med Biol 43(9):534-542. https ://doi.org/10.1016/j.nucmedbio.2016.05.011

35. Lewis JS, Herrero P, Sharp TL, Engelbach JA, Fujibayashi Y, Laforest $\mathrm{R}$ et al (2002) Delineation of hypoxia in canine myocardium using PET and copper(II)-diacetyl-bis(N4-methylthiosemicarbazone). J Nucl Med 43(11):1557-1569 notavaiable

36. Metzger JM, Moore CF, Boettcher CA, Brunner KG, Fleddermann RA, Matsoff HN, et al. (2018) In vivo imaging of inflammation and oxidative stress in a nonhuman primate model of cardiac sympathetic neurodegeneration. npj Parkinsons Dis. 4:22. doi: 10.1038/s41531-018-0057-1.

37. DeMarshall CA, Han M, Nagele EP, Sarkar A, Acharya NK, Godsey $\mathrm{G}$ et al (2015) Potential utility of autoantibodies as bloodbased biomarkers for early detection and diagnosis of Parkinson's disease. Immunol Lett 168(1):80-88. https://doi.org/10.1016/j. imlet.2015.09.010

38. Sharma S, Moon CS, Khogali A, Haidous A, Chabenne A, Ojo C et al (2013) Biomarkers in Parkinson's disease (recent update). Neurochem Int 63(3):201-229. https://doi.org/10.1016/j.neuin t.2013.06.005

39. Blasco H, Garcon G, Patin F, Veyrat-Durebex C, Boyer J, Devos D et al (2017) Panel of oxidative stress and inflammatory biomarkers in ALS: a pilot study. Can J Neurol Sci 44(1):90-95. https://doi. org/10.1017/cjn.2016.284

40. Xu R, Wu C, Zhang X, Zhang Q, Yang Y, Yi J et al (2011) Linking hypoxic and oxidative insults to cell death mechanisms in models of ALS. Brain Res 1372:133-144. https://doi.org/10.1016/j.brain res.2010.11.056

41. Zhang Z, Yan J, Chang Y, ShiDu Yan S, Shi H (2011) Hypoxia inducible factor-1 as a target for neurodegenerative diseases. Curr Med Chem 18(28):4335-4343. https://doi.org/10.2174/09298 6711797200426

42. Sedgwick AC, Brewster JT, Harvey P, Iovan DA, Smith G, He X-P et al (2020) Metal-based imaging agents: progress towards interrogating neurodegenerative disease. Chem Soc Rev 49(10):28862915. https://doi.org/10.1039/c8cs00986d

43. Duncombe J, Kitamura A, Hase Y, Ihara M, Kalaria RN, Horsburgh K (2017) Chronic cerebral hypoperfusion: a key mechanism leading to vascular cognitive impairment and dementia. Closing the translational gap between rodent models and human vascular cognitive impairment and dementia. Clin Sci. 131(19):2451-2468. https://doi.org/10.1042/CS20160727

44. Rodríguez García PL, Rodríguez GD (2015) Diagnosis of vascular cognitive impairment and its main categories. Neurologia 30(4):223-239. https://doi.org/10.1016/j.nrl.2011.12.014

45. De La Torre JC (2012) Cardiovascular risk factors promote brain hypoperfusion leading to cognitive decline and dementia. Cardiovasc Psychiatry Neurol 2012:367516. https://doi. org/10.1155/2012/367516

46. Ikawa M, Okazawa H, Arakawa K, Kudo T, Kimura H, Fujibayashi $Y$ et al (2009) PET imaging of redox and energy states in strokelike episodes of MELAS. Mitochondrion 9(2):144-148. https:// doi.org/10.1016/j.mito.2009.01.011

47. Björnheden T, Levin M, Evaldsson M, Wiklund O (1999) Evidence of hypoxic areas within the arterial wall in vivo. 
Arterioscler Thromb Vasc Biol 19(4):870-876. https://doi. org/10.1161/01.atv.19.4.870

48. Parathath S, Mick SL, Feig JE, Joaquin V, Grauer L, Habiel DM et al (2011) Hypoxia is present in murine atherosclerotic plaques and has multiple adverse effects on macrophage lipid metabolism. Circ Res 109(10):1141-1152. https://doi.org/10.1161/CIRCR ESAHA.111.246363

49. Dweck MR, Aikawa E, Newby DE, Tarkin JM, Rudd JHF, Narula $\mathrm{J}$ et al (2016) Noninvasive molecular imaging of disease activity in atherosclerosis. Cir Res 119(2):330-340. https://doi.org/10.1161/ CIRCRESAHA.116.307971

50. Hill NR, Fatoba ST, Oke JL, Hirst JA, O'Callaghan CA, Lasserson DS et al (2016) Global prevalence of chronic kidney disease-A systematic review and meta-analysis. PLoS ONE 11(7):e0158765. https://doi.org/10.1371/journal.pone.0158765

51. Matthews SJ, Lancaster JW (2011) Urinary tract infections in the elderly population. Am J Geriatric Pharmacotherapy 9(5):286309. https://doi.org/10.1016/j.amjopharm.2011.07.002

52. Risk NCD, Collaboration F (2016) Worldwide trends in diabetes since 1980: a pooled analysis of 751 population-based studies with 4.4 million participants. Lancet 387(10027):1513-1530. https://doi.org/10.1016/S0140-6736(16)00618-8

53. Wandrag L, Siervo M, Riley HL, Khosravi M, Fernandez BO, Leckstrom CA et al (2017) Does hypoxia play a role in the development of sarcopenia in humans? Mechanistic insights from the Caudwell Xtreme everest expedition. Redox Biol 13:60-68. https ://doi.org/10.1016/j.redox.2017.05.004

54. Balasubramanian S (2013) Progression of chronic kidney disease: mechanisms and interventions in retardation. Apollo Med 10(1):19-28. https://doi.org/10.1016/j.apme.2013.01.009

55. Mimura I, Nangaku M (2010) The suffocating kidney: tubulointerstitial hypoxia in end-stage renal disease. Nat Rev Nephrol 6(11):667-678. https://doi.org/10.1038/nrneph.2010.124

56. Neugarten J (2012) Renal BOLD-MRI and assessment for renal hypoxia. Kidney Int 81(7):613-614. https://doi.org/10.1038/ ki.2011.462

57. Inoue $\mathrm{T}$, Kozawa E, Okada $\mathrm{H}$, Inukai $\mathrm{K}$, Watanabe S, Kikuta $T$ et al (2011) Noninvasive evaluation of kidney hypoxia and fibrosis using magnetic resonance imaging. J Am Soc Nephrol 22(8):1429-1434. https://doi.org/10.1681/ASN.2010111143

58. Catana C, Guimaraes AR, Rosen BR (2013) PET and MR imaging: the odd couple or a match made in heaven? J Nuc Med 54(5):815-824. https://doi.org/10.2967/jnumed.112.112771

59. Li LP, Halter S, Prasad PV (2008) Blood oxygen level-dependent $\mathrm{mr}$ imaging of the kidneys. Mag Reson Imaging Clin N Am 16(4):613-625. https://doi.org/10.1016/j.mric.2008.07.008

60. Thomas R, Kanso A, Sedor JR (2008) Chronic kidney disease and Its complications. Prim Care 35(2):329-344. https://doi. org/10.1016/j.pop.2008.01.008

61. Kurutas EB, Ciragil P, Gul M, Kilinc M (2005) The effects of oxidative stress in urinary tract infection. Mediators Inflamm 4:242-244. https://doi.org/10.1155/MI.2005.242

62. Lin AE, Beasley FC, Olson J, Keller N, Shalwitz RA, Hannan $\mathrm{TJ}$ et al (2015) Role of hypoxia inducible factor- $1 \alpha$ (HIF-1 $\alpha)$ in innate defense against uropathogenic escherichia coli infection. PLoS Pathog 11(4):e1004818. https://doi.org/10.1371/journ al.ppat. 1004818

63. Sada K, Nishikawa T, Kukidome D, Yoshinaga T, Kajihara N, Sonoda $\mathrm{K}$ et al (2016) Hyperglycemia induces cellular hypoxia through production of mitochondrial ROS followed by suppression of aquaporin-1. PLoS ONE 11(7):e0158619. https://doi. org/10.1371/journal.pone.0158619

64. Biswas S, Mukherjee R, Tapryal N, Singh AK, Mukhopadhyay CK (2013) Insulin regulates hypoxia-inducible factor- $1 \alpha$ transcription by reactive oxygen species sensitive activation of $\mathrm{Sp} 1$ in 3T3-L1 preadipocyte. PLoS ONE 8(4):e62128. https://doi. org/10.1371/journal.pone.0062128

65. Lee YS, Kim JW, Osborne O, Oh DY, Sasik R, Schenk S et al (2014) Increased adipocyte O 2 consumption triggers HIF- $1 \alpha$, causing inflammation and insulin resistance in obesity. Cell 157(6):1339-1352. https://doi.org/10.1016/j.cell.2014.05.012

66. Hooton TM (2000) Pathogenesis of urinary tract infections: an update. J Antimicrob Chemother. 46(Suppl A):1-7 doi not available

67. Rowe TA, Juthani-Mehta M. Urinary tract infection in older adults. Aging Health. 2013;9(5) DOI: 10.2217/ahe.13.38

68. Barsanti C (2015) Diagnostic and prognostic utility of non-invasive imaging in diabetes management. World J Diabetes 6(6):792806. https://doi.org/10.4239/wjd.v6.i6.792

69. Bellanti F, Romano AD, Lo Buglio A, Castriotta V, Guglielmi $\mathrm{G}$, Greco A et al (2018) Oxidative stress is increased in sarcopenia and associated with cardiovascular disease risk in sarcopenic obesity. Maturitas 109:6-12. https://doi.org/10.1016/j.matur itas.2017.12.002

70. Lee K, Shin Y, Huh J, Sung YS, Lee IS, Yoon KH et al (2019) Recent issues on body composition imaging for sarcopenia evaluation. Korean J Radiol 20(2):205-217. https://doi.org/10.3348/ kjr.2018.0479

71. Jørgensen JT, Persson M, Madsen J, Kjær A (2013) High tumor uptake of $64 \mathrm{Cu}$ : implications for molecular imaging of tumor characteristics with copper-based PET tracers. Nucl Med Biol 40(3):345-350. https://doi.org/10.1016/j.nucmedbio.2013.01.002

72. Hueting R, Kersemans V, Cornelissen B, Tredwell M, Hussien K, Christlieb M et al (2014) A comparison of the behavior of 64Cu-acetate and 64Cu-ATSM in vitro and in vivo. J Nucl Med 55(1):128-134. https://doi.org/10.2967/jnumed.113.119917

73. Liu T, Karlsen M, Karlberg AM, Redalen KR (2020) Hypoxia imaging and theranostic potential of $[64 \mathrm{Cu}][\mathrm{Cu}(\mathrm{ATSM})]$ and ionic $\mathrm{Cu}$ (II) salts: a review of current evidence and discussion of the retention mechanisms. EJNMMI Res 10(1):33. https://doi. org/10.1186/s13550-020-00621-5

74. Fleming IN, Manavaki R, Blower PJ, West C, Williams KJ, Harris AL et al (2015) Imaging tumour hypoxia with positron emission tomography. Br J Cancer 112(2):238-250. https://doi.org/10.1038/ bjc. 2014.610

75. Jha NK, Jha SK, Sharma R, Kumar D, Ambasta RK, Kumar P (2018) Hypoxia-induced signaling activation in neurodegenerative diseases: targets for new therapeutic strategies. J Alzheimers Dis 62(1):15-38. https://doi.org/10.3233/JAD-170589

76. Abe H, Semba H, Takeda N (2017) The roles of hypoxia signaling in the pathogenesis of cardiovascular diseases. J Atheroscler Thromb 24(9):884-894. https://doi.org/10.5551/jat.RV17009

77. Imam SK (2010) Review of positron emission tomography tracers for imaging of tumor hypoxia. Cancer Biother Radiopharm 25(3):365-374. https://doi.org/10.1089/cbr.2009.0740

78. Fujibayashi Y, Taniuchi H, Yonekura Y, Ohtani H, Konishi J, Yokoyama A. $\mathrm{r}$ f Copper-62-ATSM : A new hypoxia imaging agent with high membrane permeability and low redox potential. J Nucl Med. 2014;1155-60 doi not available.

79. Southworth R, Martin T, de Rosales R, Meszaros LK, Ma MT, Mullen GED, Fruhwirth G et al (2016) Opportunities and challenges for metal chemistry in molecular imaging. Adv Inorg Chem 68:1-41. https://doi.org/10.1016/bs.adioch.2015.09.001

80. Lapi SE, Lewis JS, Dehdashti F (2015) Evaluation of hypoxia with Cu-ATSM. Semin Nucl Med 45(2):177-185. https://doi. org/10.1053/j.semnuclmed.2014.10.003

Publisher's Note Springer Nature remains neutral with regard to jurisdictional claims in published maps and institutional affiliations. 